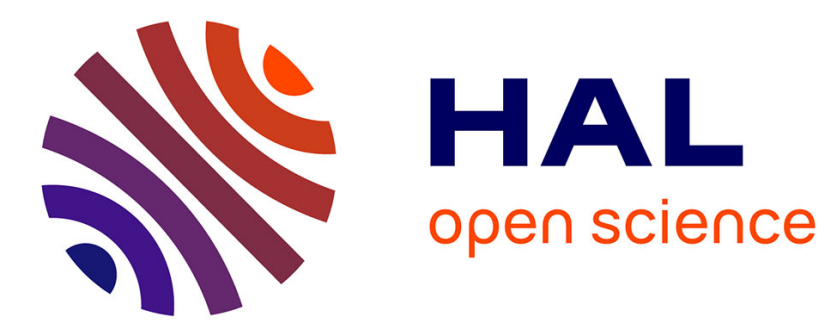

\title{
Effects of neuraminidase on equine isolated bronchi
}

\author{
M.G. Matera, L. Calzetta, A. Sanduzzi, C.P. Page, M. Cazzola
}

\section{To cite this version:}

M.G. Matera, L. Calzetta, A. Sanduzzi, C.P. Page, M. Cazzola. Effects of neuraminidase on equine isolated bronchi. Pulmonary Pharmacology \& Therapeutics, 2008, 21 (4), pp.624. 10.1016/j.pupt.2008.02.003 . hal-00499154

\section{HAL Id: hal-00499154 https://hal.science/hal-00499154}

Submitted on 9 Jul 2010

HAL is a multi-disciplinary open access archive for the deposit and dissemination of scientific research documents, whether they are published or not. The documents may come from teaching and research institutions in France or abroad, or from public or private research centers.
L'archive ouverte pluridisciplinaire HAL, est destinée au dépôt et à la diffusion de documents scientifiques de niveau recherche, publiés ou non, émanant des établissements d'enseignement et de recherche français ou étrangers, des laboratoires publics ou privés. 


\section{Author's Accepted Manuscript}

Effects of neuraminidase on equine isolated bronchi

PULMONARY

PHARMACOLOGY

\& THERAPEUTICS

M.G. Matera, L. Calzetta, A. Sanduzzi, C.P. Page, M. Cazzola

PII: $\quad$ S1094-5539(08)00018-7

DOI: $\quad$ doi:10.1016/j.pupt.2008.02.003

Reference: $\quad$ YPUPT 829

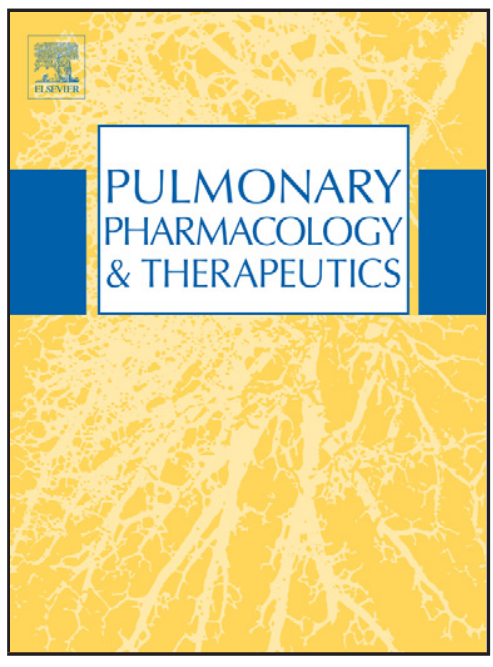

To appear in: Pulmonary Pharmacology \& Therapeutics

www.elsevier.com/locate/ypupt

Received date: 28 October 2007

Revised date: 10 February 2008

Accepted date: 19 February 2008

Cite this article as: M.G. Matera, L. Calzetta, A. Sanduzzi, C.P. Page and M. Cazzola, Effects of neuraminidase on equine isolated bronchi, Pulmonary Pharmacology \& Therapeutics (2008), doi:10.1016/j.pupt.2008.02.003

This is a PDF file of an unedited manuscript that has been accepted for publication. As a service to our customers we are providing this early version of the manuscript. The manuscript will undergo copyediting, typesetting, and review of the resulting galley proof before it is published in its final citable form. Please note that during the production process errors may be discovered which could affect the content, and all legal disclaimers that apply to the journal pertain. 


\title{
Effects of neuraminidase on equine isolated bronchi
}

\author{
M.G. Matera, L. Calzetta*, A. Sanduzzi, C.P. Page\#, M. Cazzola§
}

Department of Experimental Medicine, 2nd University of Naples, Naples, Italy, ${ }^{*}$ Department of Biothecnologies, A. Cardarelli Hospital Naples. Italy; ${ }^{\circ}$ Department ofCardiovascular and Respiratory Sciences, University of Naples Federico II, Naples, Italy;\#The Sackler Institute of Pulmonary Pharmacology, King's College London, London, UK, §Department of Internal Medicine, University of Rome 'Tor Vergata', Rome, Italy

Correspondence: Prof. Mario Cazzola, Dipartimento di Medicina Interna, Università degli Studi di Roma, Tor Vergata, Via Montpellier 1, 00133 Roma, Italy, E-mail: mario.cazzola@uniroma2.it 


\section{Abstract}

It has been demonstrated in mammals that the airway hyperresponsiveness which accompanies viral infections is the result of increased reflex bronchoconstriction due to inhibition of muscarinic prejunctional receptors, which belong to M2 subtypes. Multiple mechanisms account for virus-induced M2 receptor dysfunction. Viral neuraminidase may deglycosylate the M2 receptor, decreasing acetylcholine affinity. Equine influenza remains a common viral respiratory disease of horses worldwide, which results in loss to the equine industry, by decreasing performance, convalescence time and loss of peak performance due to chronic sequelae, such as airway hyperresponsiveness. The purpose of this study was to evaluate the effect of neuraminidase on equine isolated bronchi, assessed in equine bronchial smooth muscle rings, derived from five healthy equine male lungs. A pretreatment with vehicle did not modify contraction induced by EFS at each frequency tested. A pretreatment with pilocarpine $(1$ to $100 \mu \mathrm{M})$ significantly reduced, while methoctramine ( 1 to $100 \mu \mathrm{M})$ significantly increased contraction induced by EFS. Finally neuraminidase (0.5 UI) significantly increased contraction induced by EFS. These results suggest that airway hyperresponsiveness that follows a viral influenza infection might be related to a dysfunction of muscarinic prejunctional receptors.

Key words: equine bronchi, muscarinic autoreceptors, neuraminidase. 


\section{Introduction}

The release of acetylcholine from airway cholinergic nerves, the major bronchoconstrictor neural pathway in all mammals, is regulated by prejunctional muscarinici autoreceptors. These receptors are dysfunctional in asthmatic patients and in guinea pigs challenged by ovalbumin. Loss of function of inhibitory muscarinic autoreceptors is characterized by airway hyperresponsiveness to electrical stimulation of the vagus nerve. Furthermore, airway hyperresponsiveness to histamine in antigen challenged guinea pigs is due to increased vagally mediated reflex bronchoconstriction as a result of M2 receptor dysfunction (1-4). It has been demonstrated that both in humans and in experimental animals the airway hyperresponsiveness, observed during viral infections, is the result of increased reflex bronchoconstriction due to inhibition of M2 muscarinic receptors. Multiple mechanisms account for virus-induced M2 receptor dysfunction (5-7). Viruses and interferons, produced in response to viral infections, down-regulate the expression of M2 muscarinic receptors, and the decreased function of inhibitory M2 muscarinic receptors on the parasympathetic nerve endings is likely to contribute to increased acetylcholine release $(6,8)$. In particular, viral neuraminidase that is a major surface glycoprotein of the influenza viruses, deglycosylates M2 receptors decreasing acetylcholine affinity. This effect induces an increased release of acetylcholine from postganglionic prejunctional cholinergic nerves responsible of airway hyperresponsiveness (7-9).

Equine influenza remains a common viral respiratory disease of horses worldwide, and is usually a self-limiting disease. There are reports of respiratory signs among unvaccinated animals. In fact, this disease causes airway hyperresponsiveness, and may be a contributing factor in the development of allergic pulmonary diseases and chronic obstructive pulmonary diseases $(10,11)$. 
Although a causal relationship could not yet be determined, the clinical exacerbation of recurrent airway obstruction could be associated with virus influenza subtype 2 (11). Previous studies have demonstrated the presence of muscarinic prejunctional receptors, in horses (12, 13). These receptors modulate cholinergic neural pathway and their activation induces a significant reduction in acetylcholine release in equine isolated tracheal smooth muscles (13). We hypothesized that neuraminidase could interfere with prejunctional muscarinic receptors in the equine lung and could increase airway responsiveness. Consequently, the aim of this study was to evaluate the functional effect of neuraminidase 8 (NA) on equine isolated bronchi, in respect to the effects of pilocarpine and methoctramine.

\section{Materials and Methods}

Tissue preparations. Five healthy equine male lungs (aged 2.6 \pm 0.19 ; weighted kg 459 \pm 56.4 ) were obtained from local abattoir; all animals showed a negative history of heaves. Immediately, after resection, 3rd generation bronchi were excised, cleaned and cut in rings. Bronchial rings were transferred into organ bath containing Krebs-Henseleit buffer $(\mathrm{KH}$; composition in mM: $118.4 \mathrm{NaCl}, 25.0 \mathrm{NaHCO}_{3}, 11.7$ dextrose, $4.7 \mathrm{KCl}, 2.6 \mathrm{CaCl}_{2}, 2 \mathrm{H} 2 \mathrm{O}$, $1.19 \mathrm{MgSO}_{4} \cdot 7 \mathrm{H}_{2} \mathrm{O}$ and $1.16 \mathrm{KH}_{2} \mathrm{PO}_{4}$ with a cyclo-oxygenase inhibitor, indomethacin $5 \mu \mathrm{M}$; pregassed with $\left.=\mathrm{O}_{2} / \mathrm{CO}_{2} 95: 5 \% \mathrm{v} / \mathrm{v} ; \mathrm{pH} 7,4\right)$ at $37^{\circ} \mathrm{C}$.

Electrical field stimulation studies (EFS). Tissues were allowed to equilibrate passively for 90 min. Resting tone was adjusted to $0.5-1 \mathrm{~g}$. their responsiveness was assessed by acetylcholine (ACh) $100 \mu \mathrm{M}$; when the response reached a plateau, rings were washed three times and allowed to equilibrate for $30 \mathrm{~min}$. After full recovery of the tissues, EFS was performed by placing tissues between two wire platinum electrodes, connected to a stimulator 3165 multiplexing pulse booster (Basile Instruments, Italy). Untreated tissues were electrically 
stimulated for $10 \mathrm{sec}(10 \mathrm{~V}, 0.2 \mathrm{~ms})$ by increasing EFS frequencies $(3-10-25 \mathrm{~Hz})$. Afterward, they were washed three times and allowed to equilibrate for $30 \mathrm{~min}$.

Our protocol included three groups of experiments: in the first group, tissues were incubated with an agonist of prejunctional muscarinic receptors, pilocarpine (P; $1 \mu \mathrm{M}$ to $100 \mu \mathrm{M})$; in the second group of experiments, tissues were incubated with an antagonist of prejunctional muscarinic receptors, methoctramine $(\mathrm{M} ; 1 \mu \mathrm{M}$ to $100 \mu \mathrm{M})$; in the last group, equine bronchi were incubated with neuraminidase $\mathrm{A}^{1} \mathbf{1}(\mathrm{NA} ; 0.5 \mathrm{UI})$. In all experiments some of the tissue derived from each lung was not treated with pilocarpine, methoctramine nor neuraminidase, but was incubated with vehicle (phosphate buffer; $100 \mu \mathrm{M}$ ), and served as vehicle and time control (14). After 30 min incubation, tissues were electrically stimulated, as above described. In order to confirm that $\mathrm{P}, \mathrm{M}$ and NA exclusively affected the endogenous cholinergic responses to EFS neurally released $\mathrm{ACh}$, two additional tissues were pretreated with the sodium channel blocker tetrodotoxin (TTx, $3 \mu \mathrm{M})$ and with the muscarinic-receptor antagonist atropine (ATR, $3 \mu \mathrm{M})$, as described by Olszewski et al. (14). These latter tissues were then treated before EFS with pilocarpine $(100 \mu \mathrm{M})$ methoctramine $(100 \mu \mathrm{M})$ and neuraminidase $(0.5 \mathrm{UI})$.

At the end of the experiments, the wet weight of each tissue was determined.

Analysis of results. In the figures, contractile responses are expressed as a percentage of contraction induced by EFS at $25 \mathrm{~Hz}$ of untreated bronchi. All values are presented as mean \pm SEM. All $n$ values refer to the number of the lungs. To determine drug effects, we applied a

\footnotetext{
${ }^{1}$ Considering that $1 \mathrm{U}$ of NA8 will liberate $1.0 \mu$ mole of $\mathrm{N}$-acetylneuraminic acid per min at $\mathrm{pH} 5.0$ at $37^{\circ} \mathrm{C}$ using NAN-lactose or bovine submaxillary mucin (Warren L, 1959), that the activity of NA8 is about $30-50 \%$ as active at pH 7.0 in phosphate buffer (Cassidy JT et al., 1965) and that the Enzymatic Assay of Neuraminidase (EC 3.2.1.18) with N-Acetylneuramin-Lactose as Substrate employs $0.02-0.04$ unit/ml of Neuraminidase incubated at $37^{\circ} \mathrm{C}$ for 10 minutes (Warren L, 1959; Cassidy JT et al., 1965; Schneir ML and Rafelson ME, 1966), we have incubated bronchus rings with NA8 $0.5 \mathrm{U}(0.05$ units $/ \mathrm{ml})$ for 30 minutes in $10 \mathrm{ml}$ isolated organ bath at $37^{\circ} \mathrm{C}$ in $\mathrm{KH}$ solution.
} 
comparison of treated and untreated tissues. This excluded any effects of time or vehicle. Statistical significance was assessed by multifactorial analysis of variance (ANOVA). In presence of a significant overall ANOVA, Duncan's multiple range testing was used to identify where differences were significant. A level of probability level of $P<0.05$ was considered as significant for all tests. All data analysis was performed using computer software (GraphPad Prism, CA, USA).

Drugs. The following drugs were used: acetylcholine, methoctramine, pilocarpine, tetrotodoxin, atropine and neuraminidase 8 (Sigma, Chem. Co. St Louis, MO).

\section{Results}

Baseline characteristics of the bronchial rings. There was no significant difference ( $p>0.05)$ between each group in wet weight (C, 283 $\pm 23 \mathrm{mg} ; \mathrm{P}, 284 \pm 13 \mathrm{mg} ; \mathrm{M} 286 \pm 19 \mathrm{mg}$; $\mathrm{Na}, 187 \pm 23 \mathrm{mg})$ or contraction induced by $\mathrm{ACh} 100 \mu \mathrm{M}(\mathrm{C}, 6.6 \pm 0.65 \mathrm{~g} ; \mathrm{P}, 4.30 \pm 2.81 \mathrm{~g} ; \mathrm{M}$ $5.11 \pm 3.53 \mathrm{~g} ; \mathrm{Na}, 6.56 \pm 0.45 \mathrm{~g})$.

EFS responses of equine isolated bronchi. EFS induced a contraction, frequency dependent, in each treatment group. The responses obtained in the untreated control tissues were similar (always $P>0.05$ ) to those obtained in the control bronchi treated with vehicle ( 3 $\mathrm{Hz}$ before $2.16 \pm 0.64 \mathrm{gr}$, after $2.02 \pm 0.50 \mathrm{gr}$; $10 \mathrm{~Hz}$ before $3.22 \pm 0.74 \mathrm{gr}$. After $3.14 \pm 0.72$; $25 \mathrm{~Hz}$ before $4.54 \pm 1.04 \mathrm{gr}$, after $4.46 \pm 0.92 \mathrm{gr}$.). The time (30 min before the second EFS) did not modify the EFS induced contraction which was not statistically different at each frequency used.

Responses of prejunctional muscarinic receptors to EFS. In the first and in the second group of experiments, EFS induced a frequency dependent contraction of untreated bronchi 
(figures 1 and 2); 30 min of incubation with pilocarpine and methoctramine did not modify the baseline tone of isolated tissues. Pilocarpine reduced, in a concentration dependent manner, the contraction evoked by EFS in respect to untreated tissues at each frequency tested in respect to untreated bronchi (table 1). The effect was significant at concentrations of 10 and $100 \mu \mathrm{M}(\mathrm{P}<0.05)$ (figure 1a). On the other hand, the increased concentration of methoctramine $(1$ to $100 \mu \mathrm{M})$ significantly $(P<0.05)$ enhanced the contraction induced by EFS at each frequency tested (table 1; figure 2a) when compared with the results obtained in untreated bronchi. Both TTX and ATR abolished the responses of pilocarpine and methoctramine (figures $1 \mathrm{~b}-2 \mathrm{~b}$ ).

Effects of neuraminidase on EFS. In equine isolated bronchial rings a pretreatment with $\mathrm{NA}$, at the concentration of $0.5 \mathrm{UI}$, significantly $(P<0.05)$ increased contraction at all frequencies tested in respect to untreated tissues, as well as observed with methoctramine (table 1; figures 3 and 4). Neuraminidase did not shown any effect on baseline tension (figure 3). Both TTx and ATR completely blocked responses to EFS in the presence of neuraminidase (figure 4).

\section{Discussion}

Muscarinic receptors are considered to be of comparable clinical importance in chronic obstructive pulmonary disease (COPD) in equines and in humans $(15,16)$. Particularly, equine COPD is characterized by increased basal tone and by increased bronchoconstriction to a variety of irritants, including inflammatory mediators, mediated through the cholinergic nerves (16).

The observation that a non selective muscarinic receptor antagonist, atropine, dramatically enhanced acetylcholine release from airway cholinergic nerves, has allowed to hypothesise 
that muscarinic autoreceptors could be involved in the control of cholinergic tone in horses (17). In fact, rather than being caused by some chronic changes in nerve terminals or smooth muscle itself, e.g., by upregulation of M3 muscarinic receptors on airway smooth muscle or decreased acetylcholinesterase activity, the increase in cholinergic airway tone of horses is most likely induced by factors, such as inflammatory mediators that, when present in the airways, facilitate either local release or the response of smooth muscle to acetylcholine released by the nerves $(14,18,19)$.

Although, at the present time, data on the expression and distribution of probable subtypes of these receptors in the airway of the equine lung are scarce, recent findings indicate the presence of at least three muscarinic receptor subtypes M2, M3 and M1 distributed in trachea, bronchi, lung parenchyma and epithelium $(20,21)$. Furthermore, previous studies have demonstrated that the release of acetylcholine from equine airway cholinergic nerves is inhibited prejunctionally by inhibitory muscarinic receptors, by examining the effects of muscarinic receptor antagonists on EFS-induced acetylcholine release in trachealis preparations. These receptors, when activated, reduce the release of acetylcholine from postganglionic cholinergic efferents $(12,13)$.

In agreement with the literature, our results have confirmed the presence of muscarinic autoreceptors in equine bronchi that modulate functionally the acetylcholine release from the cholinergic nerve. We demonstrated that pilocarpine, an agonist of muscarinic prejunctional receptors, inhibited EFS-induced contraction, whereas methoctramine, an antagonist of these receptors, significantly enhanced contraction induced by EFS. The effects of pilocarpine and methoctramine on the EFS responses were due to modulation of the cholinergic endogenous tone. In fact, ATR and TTx abolished the responses to EFS in the presence of both drugs, in accordance with the data obtained by Olszewski et al. (14) who showed that peripheral 
airways from horse, in vitro, produce entirely cholinergic contractions in response to nerve stimulation by EFS.

Regardless of the muscarinic receptor subtype(s) involved, we can not exclude the possibility that muscarinic autoreceptors in equine bronchi could be different from the classical M2 receptors, but could belong to M2-like receptor, since the greatest effect of the two drugs was observed at a concentration higher than their $\mathrm{pA} 2$, as it has been demonstrated in equine isolated trachea (12). Moreover, also in other species, including humans, the comparison of the pre- and postjunctional potencies of the M1-, M2- and M3-selective antagonists has suggested that autoinhibition of acetylcholine release is mediated via an 'M2-like' receptors (22-25). In any case, even thought the muscarinic autoreceptors may be a different receptor subtype to the classical M2, the results that we obtained with pilocarpine and methoctramine were not unexpected because these drugs are receptor selective rather the receptor specific (12).

It has been shown that prejunctional muscarinic receptors appear to be completely dysfunctional in several experimental models of asthma, and also in human asthmatic patients, infected with influenza and parainfluenza virus (1-7).

The effects of viral infection on acetylcholine release and M2 receptor function may be important in explaining the effects of viral infection on airway function. It has long been recognized that viral infection are associated with exacerbation of airway diseases and that they can lead to increase vagally mediated reflex bronchoconstriction (5-9). The function of the M2 muscarinic receptor on the airway nerves is lost after viral infections in different animal models $(6,7)$. In humans, airway hyperreactivity is clearly associated with loss of neuronal M2 muscarinic receptor function $(5,6,8)$. Viral infections and their enzymes, such as neuraminidase, modify the function of muscarinic prejunctional autoreceptors (9). Particularly, 
virus and interferons produced in response to viral infection down-regulate M2 muscarinic receptor genes and viral neuraminidase cleaves sialic acid residues from muscarinic prejunctional receptors, decreasing the affinity to the receptors by 10 -fold (9).

Equine influenza remains a common viral respiratory disease of horses worldwide, which results in loss losses to the equine industry, by decreasing performance, convalescence time and loss of peak performance due to chronic sequelae $(10,11)$. Influenza viruses interfere with mucociliary clearance and may explain the common secondary bacterial complication $(10,11)$. Airway hyperresponsiveness, which also accompanies viral infection, may be a contributing factor in the development of allergic pulmonary diseases and chronic obstructive pulmonary diseases $(10,11,16)$. Acute exacerbation of recurrent airway obstruction of horses is characterized by bronchospasm, inflammation of the tracheobronchial tree, and nonspecific airway hyperresponsiveness. The rapid decrease in pulmonary resistance and increase in dynamic compliance after muscarinic blockade with atropine indicates that a large part of the bronchospasm is mediated through cholinergic mechanisms (16).

Our results here provided for the first time the experimental evidence that neuraminidase modifies muscarinic autoreceptors in horses. In fact, neuraminidase significantly enhanced bronchoconstriction induced by EFS, as well as methoctramine and influence the magnitude of endogenous cholinergic tone. Particularly the augmentation of contraction was also observed at the lower frequency tested which is the physiological frequency at which postganglionic parasympathetic nerves are thought to periodically fire in the equine airways (14).

Regardless of the mechanism by which neuraminidase exerted its' effect on EFS responses, we have shown that this enzyme influences the magnitude of cholinergic responses in equine bronchi. In fact, its effects were completely abolished by a pre-treatment with ATR and TTx 
performed to confirm their prejunctional and cholinergic nature. As well as demonstrated in other species (5-9), they might be related to a modified muscarinic autoreceptor function that increased acetylcholine release from airway cholinergic nerves. It is possible that this dysfunction might contribute to the exacerbation of COPD in the horse, but it might also provide potential drug targets for the therapeutic use in these species (26). It has been considered a suitable target for designing agents against influenza viruses. Rational drug design of NA inhibitors is now on the market and available to patients. These drugs might prevent airway complications that follow viral infection.

In conclusion, our results suggest that airway hyperresponsiveness due to a viral influenza infection in equine might be related to dysfunctional muscarinic prejunctional receptors. 


\section{References}

1. Fryer $A D$, Maclagan J. Muscarinic inhibitory receptors in pulmonary parasympathetic nerves in the guinea-pig.Br J Pharmacol 1984; 83: 973-978.

2. Minette $P$, Barnes PJ. Prejunctional inhibitory muscarinic receptors on cholinergic nerves in human and guinea pig airways. J Appl Physiol 1988; 64: 2532-2537.

3. Patel HJ, Barnes PJ, Takahashi T, Tadjkarimi S, Yacoub MH, Belvisi MG. Evidence for prejunctional muscarinic autoreceptors in human and guinea pig trachea. Am J Respir Crit Care Med 1995;152: 872-878.

4. Fryer $A D$, Wills-Karp $M$. Dysfunction of $m 2$-muscarinic receptors in pulmonary parasympathetic nerves after antigen challenge. J Appl Physiol 1991; 71:2255-61.

5. Jacoby DB. Pathophysiology of airway viral infections. Pulm Pharmacol Ther 2004; 17: 333-336.

6. Jacoby DB, Fryer AD. Interaction of viral infections with muscarinic receptors. Clin Exp Allergy 1999; 29:59-64.

7. Fryer $A D$, el-Fakahany EE, Jacoby DB. Parainfluenza virus type 1 reduces the affinity of agonists for muscarinic receptors in guinea-pig lung and heart. Eur $\mathrm{J}$ Pharmacol 1990; 181: 51-58.

8. Jacoby $D B$, Xiao H-Q, Lee NE, Chan-Li Y, Fryer A. Virus- and interferons-induced loss of inhibitory M2 muscarinic receptor function and gene expression in cultured airway parasympathetic neurons. J Clin Invest 1998; 102: 242-248.

9. Fryer $A D$, Jacoby $D B$. Parainfluenza virus infection damages inhibitory $m 2$ muscarinic receptors on pulmonary parasympathetic nerves in the guinea-pig. Br J Pharmacol 1991; 102: 267-71.

10. Sutton GA, Viel L, Carman PS, Boag BL. Study of the duration and distribution of equine influenza virus subtype 2 (H3N8) antigens in experimentally infected ponies in vivo. Am J Vet 1997; 61:113-120.

11. Costa LR, Johnson JR, Baur ME, Beadle RE. Temporal clinical exacerbation of summer pasture-associated recurrent airway obstruction and relationship with climate and aeroallergens in horses. Am J Vet Res 2006; 67:1635-1642.

12. Wang ZW, Yu MF, Robinson NE. Prejunctional muscarinic autoreceptors on horse airway cholinergic nerves. Life Sci 1995; 56: 2255-2262.

13. Wang ZW, Yu MF, Robinson NE, Derksen FJ. Acetylcholine release from airway cholinergic nerves in horses with heaves, an airway obstructive disease. Am J Respir Crit Care Med 1995; 151: 830-835. 
14. Olszewski MA, Robinson NE, Zhu FX, Tithof PK. Mediators of anaphylaxis but not activated neutrophils augment cholinergic responses of equine small airways. $A m \mathrm{~J}$ Phisiol Lung Cell Mol Physiol 1999; 276: L522-L529.

15. On LS, Boonyongsunchai P, Webb S, Davies L, Calverley PM, Costello RW. Function of pulmonary neuronal $\mathrm{M}(2)$ muscarinic receptors in stable chronic obstructive pulmonary disease. Am J Respir Crit Care Med 2001; 163:1320-1325.

16. Robinson NE, Derksen FJ, Olszewski MA, Buechner-Maxwell VA. The pathogenesis of chronic obstructine pulmonary disease of horses. Br J Vet 1996: 125: 283-306.

17. Broadstone RV, Scott JS, Derksen FJ, Robinson NE. Effects of atropine in ponies with recurrent airway obstruction. J Appl Physiol 1988; 65: 2720-2725.

18.17.Yu M, Wang ZW, Robinson NE, Derksen FJ. Modulation of bronchial smooth muscle function in horses with heaves. Clin Exp Allergy 1995: 25: 51-59.

19. Wang Z, Yu M, Robinson NE, Derksen FJ. Acetylcholine release from airway cholinergic nerves in horses with heaves. Am J Respir Crit Care Med 1995: 151: 830835.

20. Torneke K, Ingvast-Larsson C, Bostrom A, Appelgren LE. Muscarinic receptors in equine airways. Vet Res Commun 2002; 26:637-50

21. Abraham G, Kottke C, Ammer H, Dhein S, Ungemach FR. Segment-dependent expression of muscarinic acetylcholine receptors and G-protein coupling in the equine respiratory tract. Vet Res Commun 2007; 31:207-26.

22. Roffel AdJ, Davids JH, Elzinga CRS, Wolf D, Zaagsma J. Characterization of the muscarinic receptor subtype(s) mediating contraction of guinea pig lung strip and inhibition of acetylcholine release in the guinea pig trachea with the selective muscarinic receptor antagonist tripitramine. Br J Pharmacol 1997; 122: 133-141.

23. Garssen J, Van Loveren $H$, Gierveld CM, Van der Vliet H, Nijkamp FP. Functional characterization of muscarinic receptors in murine airways. Br J Pharmacol 1993;109: 53-60.

24. Del Monte $M$, Omini $C$, Subissi A. Mechanism of potentiation of neurally-induced bronchoconstriction by gallamine in the guinea pig. Br J Pharmaco 1990; 99: 582-586.

25. Kilbinger H, Schneider R, Siefken H, Wolf D, D'Agostino G. Characterization of prejunctional muscarinic autoreceptors in the guinea-pig trachea. $\mathrm{Br} \mathrm{J}$ Pharmacol 1991;103:1757-1763.

26.Zhang J, Xu W. Recent advances in anti-influenza agents with neuraminidase as target. Min Rev Med Chem 2006; 6:429-448. 


\section{Table 1.}

Effects of pilocarpine (P; 1 to $100 \mu \mathrm{M})$, methoctramine $(\mathrm{M} ; 1$ to $100 \mu \mathrm{M})$, and neuraminidase (NA; $0.5 \mathrm{UI})$ on the contraction induced by EFS in equine isolated bronchi. Responses are presented as grams of contraction. Each value is the mean $\pm S D$ of five samples. ${ }^{*} P<0.05$ vs untreated tissues.

\begin{tabular}{lcccccc}
\hline & \multicolumn{2}{c}{$3 \mathrm{~Hz}$} & \multicolumn{2}{c}{$10 \mathrm{~Hz}$} & \multicolumn{2}{c}{$25 \mathrm{~Hz}$} \\
\cline { 2 - 7 } & $\mathrm{U}$ & $\mathrm{T}$ & $\mathrm{U}$ & $\mathrm{T}$ & $\mathrm{U}$ & $\mathrm{T}$ \\
\hline & & & & & & \\
$\mathrm{P} 1 \mu \mathrm{M}$ & $1.20 \pm 0.38$ & $1.27 \pm 0.28$ & $2.09 \pm 0.66$ & $1.62 \pm 0.29$ & $2.85 \pm 0.67$ & $1.65 \pm 0.29^{*}$ \\
$\mathrm{P} 10 \mu \mathrm{M}$ & $1.29 \pm 0.35$ & $0.69 \pm 0.23^{*}$ & $2.30 \pm 0.35$ & $0.89 \pm 0.18^{*}$ & $3.56 \pm 0.84$ & $1.35 \pm 0.30^{*}$ \\
$\mathrm{P} 100 \mu \mathrm{M}$ & $2.41 \pm 1.11$ & $0.88 \pm 0.58^{*}$ & $4.36 \pm 1.91$ & $0.90 \pm 0.60^{*}$ & $5.61 \pm 2.13$ & $1 . .33 \pm 0.97^{*}$ \\
\hline & & & & & & \\
$\mathrm{M} 1 \mu \mathrm{M}$ & $1.44 \pm 0.39$ & $1.60 \pm 0.37^{*}$ & $2.18 \pm 0.76$ & $2.82 \pm 0.79^{*}$ & $3.09 \pm 0.83$ & $3.35 \pm 0.91^{*}$ \\
$\mathrm{M} 10 \mu \mathrm{M}$ & $1.35 \pm 0.54$ & $1.84 \pm 0.42^{*}$ & $2.42 \pm 0.27$ & $3.23 \pm 1.23^{*}$ & $3.34 \pm 0.87$ & $3.86 \pm 1.05$ \\
$\mathrm{M} 100 \mu \mathrm{M}$ & $2.06 \pm 0.56$ & $2.61 \pm 0.91^{*}$ & $2.60 \pm 0.52$ & $3.64 \pm 1.14^{*}$ & $3.47 \pm 0.68$ & $4.75 \pm 1.49^{*}$ \\
\hline & & & & & & \\
$\mathrm{NA} 0.5 \mathrm{UI}$ & $1.28 \pm 0.48$ & $2.23 \pm 0.64^{*}$ & $1.87 \pm 0.61$ & $3.25 \pm 0.67^{*}$ & $3.06 \pm 0.72$ & $4.90 \pm 0.69^{*}$ \\
\hline
\end{tabular}


Figure 1. Effects of pilocarpine (1,10 and $100 \mu \mathrm{M}$; black labels) on cholinergic responses, compared with untreated bronchi (open labels). EFS after pilocarpine $100 \mu \mathrm{M}$ was carried out in the absence $(A ; n=5)$ or presence $(B ; n=5)$ of atropine (ATR; +labels) or tetrodotoxin (TTx; xlabels). Responses are expressed as the percentage of tissue contraction induced by EFS $25 \mathrm{~Hz}$ on untreated bronchi. *Significantly different from the results obtained with untreated tissues.

$1 \mathrm{~A}$

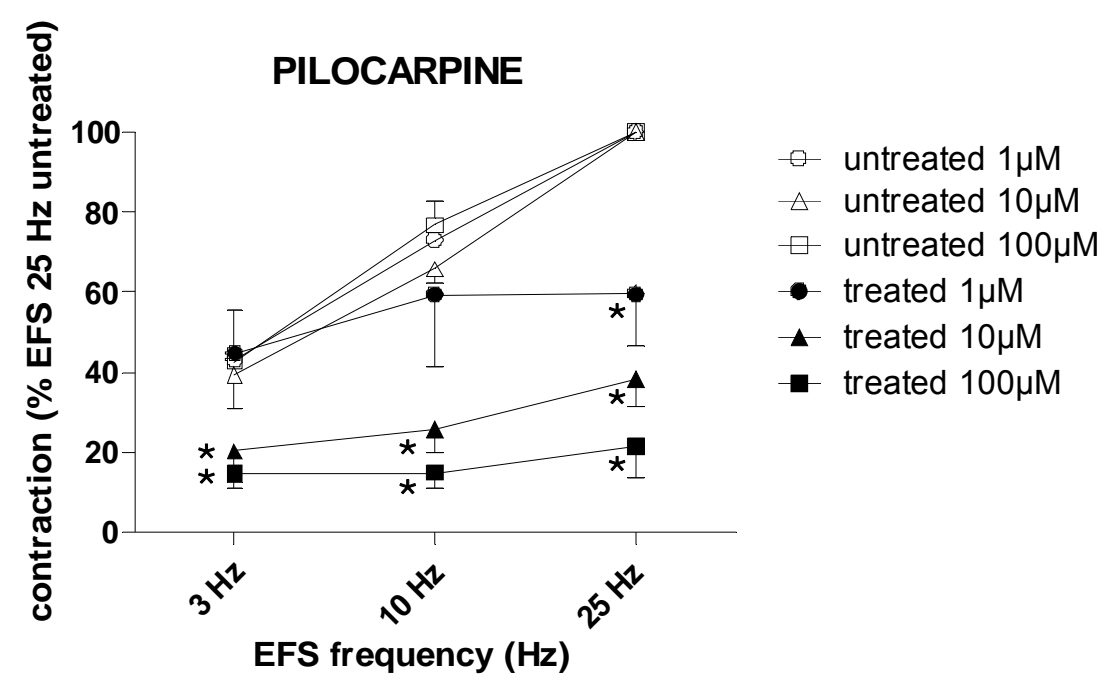

$1 \mathrm{~B}$

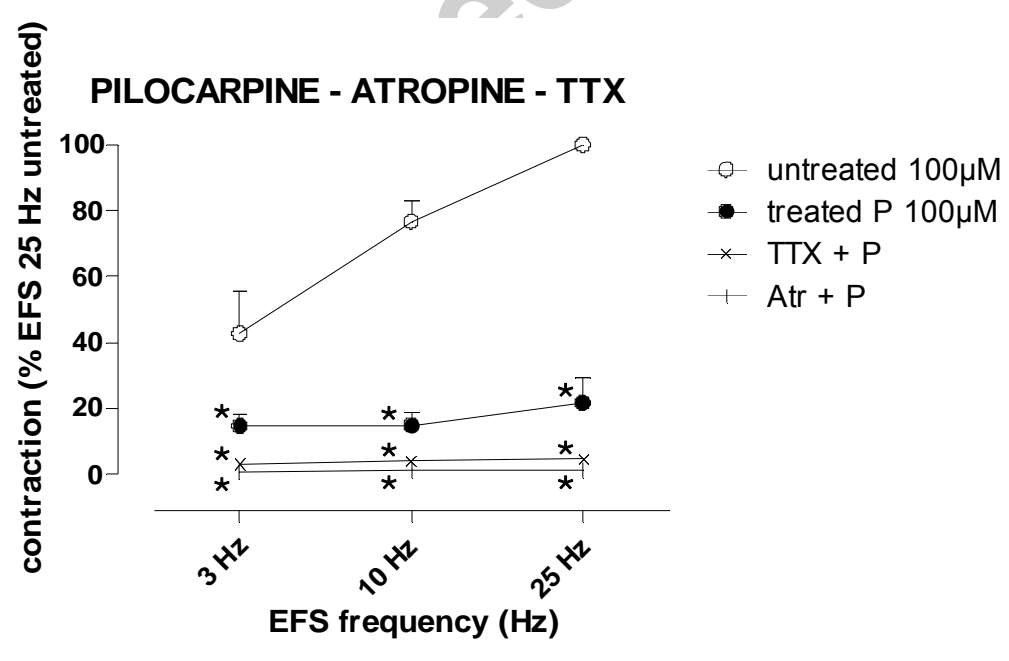


Figure 2. Effects of methoctramine $(1,10$ and $100 \mu \mathrm{M}$; black labels) on cholinergic responses, compared with untreated bronchi (open labels). EFS after methoctramine $100 \mu \mathrm{M}$ was carried out in the absence $(A ; n=5 ;)$ or presence $(B ; n=5)$ of atropine (ATR; +labels) or tetrodotoxin (TTx; xlabels). Responses are expressed as the percentage of tissue contraction induced by EFS $25 \mathrm{~Hz}$ on untreated bronchi. *Significantly different from the results obtained with untreated tissues.

$2 \mathrm{~A}$

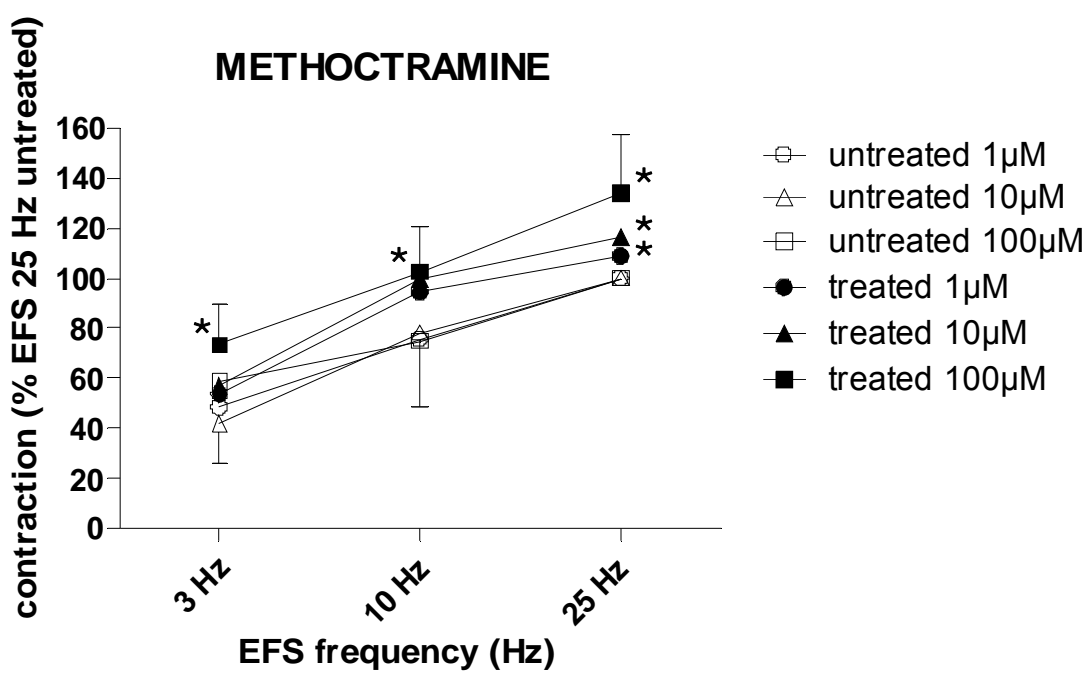

2 B

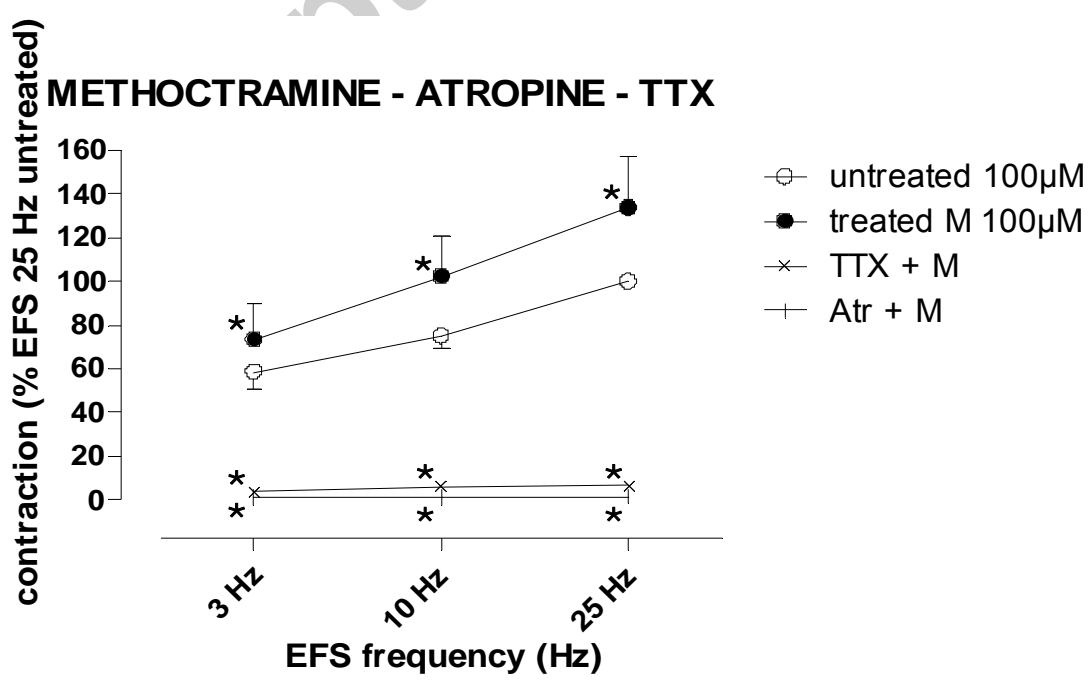


Figure 3. Effects of 30 min neuraminidase $(0.5 \mathrm{UI})$ incubation on EFS-induced contraction at three different frequencies (3-10-25 Hz). A pretreatment with NA significantly enhanced EFS induced contraction at all frequencies tested and showed no effect on baseline tension.

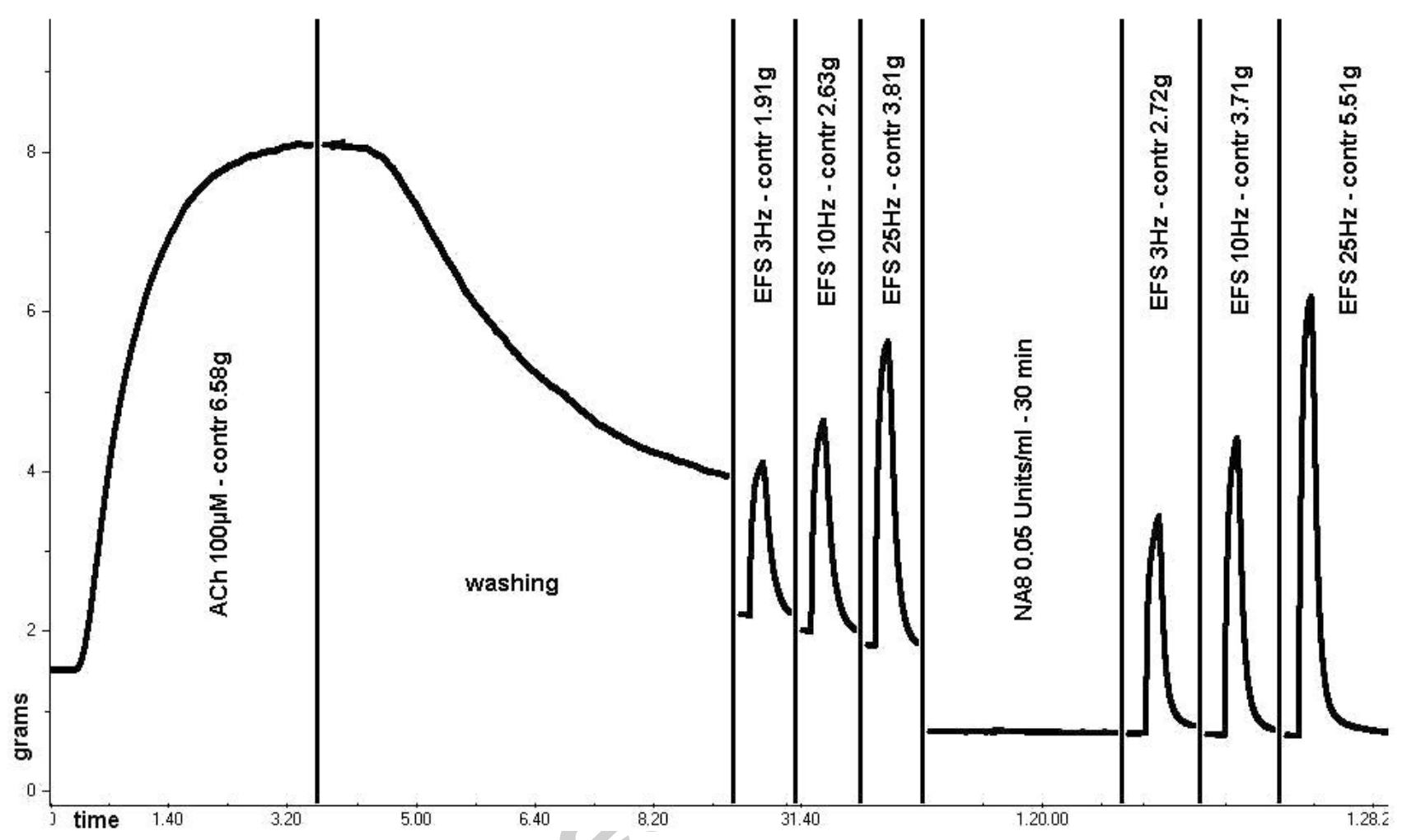


Figure 4. Effects of neuraminidase ( $0.5 \mathrm{UI}$; black labels) on cholinergic responses, compared with untreated bronchi. EFS was carried out in the absence $(n=5)$ or presence $(n=5)$ of atropine (ATR; +labels) or tetrodotoxin (TTx; xlabels). Responses are expressed as the percentage of tissue contraction induced by EFS $25 \mathrm{~Hz}$ on untreated bronchi. *Significantly different from the results obtained with untreated tissues.

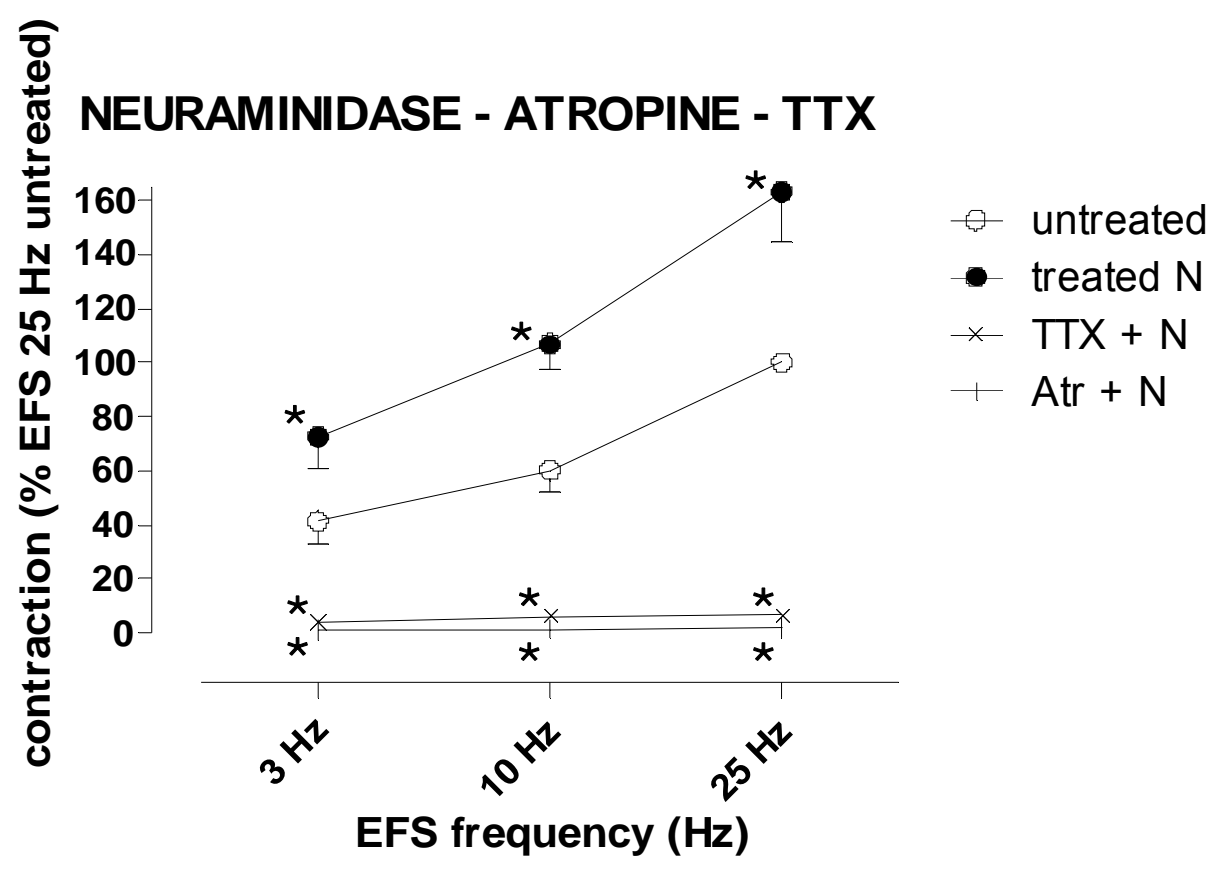

